Volume 19 Number 1 June 2019.p.129-150

https://doi.org/10.30603/au.v19i1.729

\title{
Logics, Objectives And Sociological Sides of Islamic Law:
}

Re-Structuring Fiqh For Social Change

\author{
JM. Muslimin
}

Sekolah Pascasarjana UIN Syarif Hidayatullah Jakarta

\begin{abstract}
Can Islamic law change the conservation paradigm into transformation? If possible, which aspects can be done for this matter? How far the linkage between conventional Islamic law and social adaptation can continue to be elaborated? Where can the linkage aspects between Islamic law, structure, and culture be found? That is among the several questions to be answered in this paper. Reflecting on conventional (Western) law, writing tries to compile the links between aspects of Islamic law, social and cultural structures. The article concludes with an emphasis on the importance of understanding the beginnings of the growing systematization of Islamic law, as well as the relative aspects of systematization and the necessity of understanding the socio-cultural settings that are constantly changing in the current period. So, it can produce transformative Islamic legal patterns. Islamic law that corresponds to social change.
\end{abstract}

\section{Logika, Tujuan dan Aspek Sosiologis Hukum Islam \\ Restrukturisasi Fiqh untuk Perubahan Sosial}

\begin{abstract}
Abstrak
Bisakah hukum Islam mengubah paradigma konservasi menjadi transformasi? Jika memungkinkan, aspek apa yang dapat dilakukan untuk masalah ini? Seberapa jauh hubungan antara hukum Islam konvensional dan adaptasi sosial dapat terus dielaborasi? Di mana aspek keterkaitan antara hukum, struktur, dan budaya Islam dapat ditemukan? Itulah beberapa pertanyaan yang harus dijawab dalam tulisan ini. Berkaca pada hukum konvensional (Barat), tulisan berusaha menyusun hubungan antara aspek-aspek hukum Islam, struktur sosial dan budaya. Artikel ini diakhiri dengan penekanan pada pentingnya memahami awal mula berkembangnya sistematisasi hukum Islam, serta aspek-aspek relatif dari sistematisasi dan perlunya memahami pengaturan sosial-budaya yang terus berubah pada periode saat ini. Jadi, itu bisa menghasilkan pola hukum Islam yang transformatif. Hukum Islam yang sesuai dengan perubahan sosial.
\end{abstract}

Kata Kunci: Logics, Objectives, Sociological Sides, Islamic Law

Author correspondence

Email: jm.musliminuinjkt.ac.id

Available online at http://journal.iaingorontalo.ac.id/index.php/au/index 


\section{A. Introduction}

In Islamic literature, two terms are used to refer to Islamic law namely alsyañat al-Islämiyyah and al-fiqh al Islämiy'. Some experts claim that the term Islamic law which became popular and used as an official term for example in Indonesia is the equivalent of Western terms. In English terms, there is an Islamic law nomenclature. The Islamic law-word is often used by Western writers in their works. The word is often used to designate the Arabic term Islamic jurisprudence or Islamic law in general. $^{2}$ Meanwhile, the well-known Pakistani writer, Ahmad Hasan, uses the terms Islamic Jurisprudence for Islamic law (ușül fiqh) and practical (fiqh) in his work as in the book The Early Development of Islamic Jurisprudence (1970) and The Principles of Islamic Jurisprudence (1994). ${ }^{3}$

The term Islamic law itself was not originally found in the Qur'an, Sunnah, or Islamic literature. It is a reflection of the development and dynamics of people's lives in accordance with the situation and conditions of the times. In general, what is meant by Islamic law is Islamic sharia originating from the Qur'an and Sunnah that have not been interfered with reasoning power (ijtihād), or fiqh, namely Islamic law originating from an understanding of sharia or understanding of texts, both the Qur'an ijtihädi and Sunnah. ${ }^{4}$

According to the terms and in the understanding of Muslims, shañ'ah are provisions or laws that Allah has ordained for his servants (especially those that have been categorized as legal subjects) through the intermediary of His apostle by which the legal subjects will get definite norms. ${ }^{5}$ These provisions are related to aqeedah, 'amaliyyah even to the social order of the community. So, traditionally, shant'ah is divided into three important categories. First, the teachings of the faith which would later be referred to as the knowledge of usuluddin. Second, moral teachings and ethics are the objects of morality and Sufism. ${ }^{6}$ Third, legal teachings relating to al 'amaliyyah or daily life can be referred to as objects of the science of fiqh. ${ }^{7}$ In terms of, fiqh itself

\footnotetext{
${ }^{1}$ Mahmūd Syaltūt, Al-Islām Aqīdat wa Syarī'at (Kairo: Dār al-Qalam, 1966) 9-10.

${ }^{2}$ Marzuki, Tinjauan Umum Tentang Hukum Islam (Jakarta: Mizan, 2003), 8.

3 Ahmad Hasan, The Principles of Islamic Jurisprudence: The Command of the Shari'ah and Juridical Norm (New Delhi: Adam Publishers \& Distributors, 1994), 394.

${ }^{4}$ Marzuki, Tinjauan Umum Tentang Hukum Islam, 10

${ }^{5}$ Samir 'Aliyah, 'Ilm al-Qānūn wa al-Fiqh al-Islāmī, 77.

${ }^{6}$ Ali Ahmad al-Jurjani, Hikmah al-Tashri' wa Falsafatuh (Beirut; Dar al-Fikr al-Maraghi, 1996), 55.

${ }^{7}$ Samir 'Aliyah, 'Ilm al-Qānūn wa al-Fiqh al-Islāmì (Beirut: Muassasah al-Jami'ah, 1996), 49.
} 
is a scientific discipline that discusses the detailed laws of shan 'ah related to the actions of mukallaf people. ${ }^{8}$ Classical and contemporary scholars, Al-Amidi $(631 \mathrm{H})$ and Wahbah al-Zuhaili $(1436 \mathrm{H})$ said that fiqh is a discipline about the practical law of shañ'ah from detailed arguments. The arguments here can be of nature directly from nas and also from ijtihād scholars. ${ }^{9}$ At least, there are 24 places in the Qur'an in different verses and letters that use the origin of the word fiqh. ${ }^{10}$

\section{B. Sources of Islamic Law: Building Logics and Legal Reasoning}

The source of law can be interpreted as the origin of dogmatism, theory, and understanding of the law. Often the source of Islamic law is also said to be the proposition of Islamic law or the basis of Islamic law. ${ }^{11}$ From this source, it will be illustrated how the beginning of distance occurred and at the same time there began to be an approach between the text towards the process of understanding, towards the formulation and then a series of norms, methods, and rules of law were born. Of course, it is possible that in the process there are various opinions and content of ambiguous epistemological and methodological problems.

Thera are at least three sources of Islamic law namely al-Qur'ān, al-Sunnah and Ijtihād. $^{12}$

\section{Al-Qur'ān}

In the Qu'ran study treasure, the Arabic-language Al-Qur'an is categorized as the greatest miracle of the prophet Muhammad from Allah. Then it was quoted by the next generation by the method of written transmission starting from Surah al Fätihah to the end of Surah al-Nâs. ${ }^{13}$ Muhammad al-Syaukani $(1834 \mathrm{M})$ wrote, how is the dogmatic understanding and belief of Muslims towards the Qur'an: ${ }^{14}$

\footnotetext{
8 Jamaluddin Muhammad bin Makarram bin Mandzur, Lisān al-'Arab (Beirut: Dar al-Fikr, 1990), 40. And Masyfuk Zuhdi, Pengantar Hukum Syari’ah (Jakarta: Haji Mas Agung, 1987), 5-8.

${ }^{9}$ Saifuddin Al-Amidi, al-Ihkām fi Ulūl al-Ahkām (Beirut: Dar al-Fikr, 1981), 1st publishing, 5. See also Wahbah Zuhaili, translation of Fiqh Imam Syafi 'i. (Jakarta: Al-Mahira, 2010), 220.

${ }^{10}$ Muhammad Fuad Abd al-Baqi, al-Mu'jam al-Mufahras li al-Alfādz al-Qur'ān al-Karìm (Beirut: Dar al-Fikr, 1989), 18. And see also Samir 'Aliyah, 'Ilm al-Qānūn wa al-Fiqh al-Islāmī, 77.

${ }^{11}$ Poerwadarminta, Kamus Umum Bahasa Indonesia (Jakarta: Balai Pustaka, 1976), 975.

12 Abu Hamid M. al-Ghazali, al-Muștafā min 'ilm al-Ușūl (Beirut: Muassasat al-Risalah, 1997), 1st juz, 104. See also Yasin Dutton, Asal Mula Hukum Islam (Yogyakarta: Islamika, 2003), 331.

13 Shaifuddin Al-Amidi, al-Ihkām fi Ușūl al-Ahkām (Beirut: Dar al-Fikr, 1981), Cet. 1, 5. See also Wahbah Zuhaili, Fiqh Imam Syafi'i, terj. (Jakarta: Al-Mahira, 2010), 220.

${ }^{14}$ Muhammad Ibn Ali Ibn Muhammad al-Syaukani, Nail al-Auțār (Beirut: Dar al-Fikr, 1978), 26.
} 
1. The Qur'an is the word of Allah revealed directly to the Prophet Muhammad

2. The Qur'an is revealed in Quraysh Arabic

3. The Qur'an is quoted and transmitted to generations. This generation is the guardian of the Qur'an. And at the same time, the Qur'an is revealed to all cross-cultural, time and territorial communities.

4. Reading every word in the Qur'an is worship and getting merit

5. The Qur'an starts with Surah al-Fätihah and ends with Surah an-Nās.

Such an understanding of Qu'ran is a basic belief. Then it became the dogmatism of Islamic law. There are many debates and discussions about the Koran itself among Muslims. For example, there is a debate about Jadid and its Qadim; there is a debate about the writing process; also about the kinds of qiraah al-Quran itself. It also includes debates about the understanding and interpretation of the texts. Whatever the differences, the Muslims consider the Qur'an to be a guideline and the fundamental source of Islamic law.

Returning to the debate in the Qur'an above, if we pay close attention to the clarity of the contents of the Qur'an, then there are Muhkam verses in the Qur'an. Namely, the meaning is clear and revealed clearly. Can be understood simply and quickly. Whereas the second is the mutasyäbih verses, namely verses that are uncertain in meaning and meaning, their meanings are veiled and must be explored and elaborated with various approaches to understanding them. He must be understood with several possibilities.

Furthermore, in terms of the Quranic explanation of the law, there are several ways that must be used as follows: ${ }^{15}$

1. By juzt or in detail, the meaning is that the Qur'an explains it in detail, the explanation is complete so that if someone reads it, one can carry it out according to what it is, without needing to be explained again by al-Sunnah.

2. By kulh or globally, the point is that the Qur'an explains it only in outline so that to understand and implement it is necessary to a more detailed explanation of al-Sunnah.

\footnotetext{
${ }^{15}$ Tengku Muhammad Hasbi al-Shidqi, Sejarah dan Pengantar Ilmu al-Qur'an dan Tafsir (Semarang: Pustaka Rizki Putra, 2000), 156.
} 
3. In ishärah, the meaning of the Qur'an is to explain only in the form of an explanation of cues, meaning that besides it has a written meaning, it also has another meaning implicitly. This one verse of the Qur'an can provide several specific purposes.

What is explained in juz'i is relatively small in number. But the things that are explained in an authentic and isyäri are more dominant.

\section{Al-Sunnah}

Sunnah according to language means the road, the usual path or the usual way. ${ }^{16}$ According to the term Sunnah, everything that is narrated from the Prophet Muhammad SAW, whether it is in the form of actions, sayings or provisions or agreements, characteristics, couplings, even good morals or biographies, whether done before Prophethood or after Prophethood. ${ }^{17}$

With the above definition, it can be concluded that al-Sunnah can be classified into three, namely al-sunnah al-fi 'liyyah (sunnah in the form of deeds), al-sunnah alqauliyyah (sunnah in the form of sayings) and al-sunnah al -taqrinriyyah (sunnah in the form of statute). Regarding the sunnah al-fi'liyyah, a question arises, do all the actions of the Prophet Muhammad contain laws and must be followed by his ummah? ${ }^{18}$ In this case the Fathi al-Duraini divides the al-sunnah al-fi'liyyah, into three parts like the following: ${ }^{19}$

1. Acts that emerged from the Prophet Muhammad because he was an ordinary human. For example, eating, drinking, sitting or dressing him, then actions like this are not obligatory for followers to follow.

2. Acts carried out by the Messenger of Allāh which those actions were only for himself. For example, marrying women more than four people at the

\footnotetext{
${ }^{16}$ This understanding is based on the hadith of the Prophet Muhammad, he said:

Meaning:

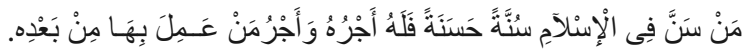

"Whoever is accustomed to something good in Islam then he receives his reward and the reward of the people afterward who practice it. "(H.R. Muslim). See Muhammad Ajaj al Khatib, Ușul al-Hadith: 'Ulūmuhu wa Muștalāhuhu (Beirut: Dar al-Fikr, 1981), 7.

${ }_{17}^{17}$ Abdul Karim Zaidan, al-Madkhal li al-Dirāsāt al-Islāmiyyah (Kairo: Dar Umar bin Khattab, t.t), 195.

${ }_{18}^{18}$ Muhammad Ajaj al-Khatib, Ușūl al-Hadith: 'Ulūmuhu wa Muștalāhuhu, 40.

19 Fathi al-Duraini, al-Fiqh al-Islāmi al-Muqāran ma'a al-Madzāhib (Damaskus: Mathba'ah Tarabin, 1979), 62.
} 
same time, it is obligatory to pray for tahajjud or not to accept zakăt, then this act is of course only specific to the Prophet Muhammad alone, and is not obligatory for followers to follow.

3. Actions related to law and their legal basis. This certainly ranges between wajib, sunnah, harām, makrūh and mubāh. It was this act which eventually became a shari'ah in Islam.

That is sunnah, it is the second main source in Islamic law after the Koran. However, not all sunnah contain legal values and practices that must be followed. Besides, he has many arguments, Ijmā Radiyallahu'anhum friends can be seen in the letter Ali Imran verse 31, surah al-Ahzab verse 21 and surat al-Hasyr verse 7. Rasul SAW also once said which means: "Indeed, I have been revealed by the Qur'an and the like". The majority of scholars say that what is meant by "the like" in this hadith is the Sunnah. $^{20}$

\section{Ijtihād}

According to Arabic, the word ijtihād comes from the root word Ijtahada Yajtahidu which means it is serious or in other languages sacrifices all abilities, both body and soul for a work done because there is a purpose sought, both material and mind. Therefore, it is legitimate to call ijtihäd or mujtahid for a judge who solemnly completes case files that enter his desk. ${ }^{21}$

Whereas, according to the term ijtihäd is the mobilization of all the capabilities of the mujtahid (someone who is an expert in ijtihäd) in seeking knowledge about the laws of shar'i by means of istinbat (issuing the law from the source). ${ }^{22}$

Thus, ijtihäd is one of the bases in the development of Islamic law. The role of ijtiha $\bar{d}$ is very large in the renewal of Islamic law itself. Because it is impossible to materialize without the presence of a mujtahid or someone who has met the requirements and is able to carry out ijtihād. ${ }^{23}$

\footnotetext{
${ }^{20}$ Ali Hasaballah, Ușūl al-Tashrī’ al-Islāmī (Kairo: Dar al-Ma'rifah, 1976), 35.

${ }^{21}$ Abdul Mun'im al-Namr, al-Ijtihād (Kairo: al-Haiah al-Misriyyah al-'Ammah, 1987), 26.

${ }^{22}$ Addul Karim Zaidan, al-Wajiz fi Ușūl al-Fiqh (Baghdad: Maktabah al-Quds, 1987), 400.

${ }^{23}$ Abdul Manan, Reformasi Hukum Islam di Indonesia (Jakarta: Raja Grafindo Persada, 2006), 165.
} 


\section{Reason And Revelation in Islamic Law}

In conducting ijtihàd, according to ulama, there are several methods that can be taken by the mujtahid, both individual ijtihad or collective one. Among these methods are ijmāa ', qiyās, istịhsān, istiṣhhāb, al-maṣ lahahal-mursalah istiṣhāa b, 'urf and so on.

First, ijmā '; according to the ulama ușul fiqh is an agreement of the mujtahid of the Muslims at a time after the death of the Prophet Muhammad on the law of shara'. For example, an agreement made by some people who are not experts in ijtihād, this cannot be said to be ijmā. As for the quality of $i j m \bar{a}$ 'it is divided into two namely; ijmā șarih, meaning it is ijmā' all mujtahid as a whole they agree and there are no differences of opinion, both words, and deeds). And ijmā 'sukūti, the meaning is the opposite of ijmà' sarih, where all mujtahids do not all agree that their position is unknown whether they agree or not. ${ }^{24}$

Second, qiyās, according to Arabic qiyās is equating, measuring or comparing. Whereas according to the term is to equate the law of the case which has no meaning, with the case law there is nạs because there is the same "illat. ${ }^{25}$ For example, the statute stipulates that the recipient of the will does not get the item that was given to him when he killed the will. This was revealed to the murder carried out by heirs.

The similarity of 'illat between the two is killing or hastening something before the time. So it is clear that a law stipulated with this qiyās, is actually not a new law, but it is only the application of the law that has been established by nas.

Third, al-istihsān; The discussion at al-istiḥsān was first coined by Imam Abu Hanifah. Imam Abu Hanifah is said to often set the law by means of al-istihsānn. It's just that he hasn't explained much about why he set a law in this way. When he sets a law, he will say; "Astahsin" (I consider it good). This kind of law was then followed by his friends and followers. ${ }^{26}$ This istihsan pattern becomes a productive door for the discovery and conclusion of dynamic law.

\footnotetext{
${ }^{24}$ See Muhammad Abdul Karim al-Syarastani, al Miāl wa al-Nihāl (Cairo: Mustafa al-Bab al-Halabi, 1967), 57.

${ }^{25}$ Abu Muhammad Zahrah, al-Jarìmah wa al-'Uqūbah fi Fiqh al-Islāmī (Kairo: Dar al-Fikr al-'Arabi, 1958), 227.

${ }^{26}$ Muhammad Hasbih al-Shidqdy, Falsafah Hukum Islam (Jakarta: Bulan Bintang, 1988), $1^{\text {st }}$ publishing, 478-479. See also 'Ata Ibn al-Khalil, Kajian Ushul Fiqh Mudah dan Praktis (Bogor: Pustaka Toriq alIzzah, 2008), 113.
} 
The istiḥsān based reasoning is divided into three important things, namely; ${ }^{27}$

1. Istih̆sān bi al-naș is istih̆ān which is based on a nas but he wants not to use the other naș, because naṣ the others are kult (global), whereas naṣ which is used is khas (special or exception) For example, bai' as salam transaction ( buying and selling things that don't exist). In general, bai' as salam transaction may not be, the argument is the hadith of the Prophet Muhammad who said that لاتبيع ماليس عندك, which means "do not sell what is not by your side". general character. For example, the hadith from Ibn Abbas $(68 \mathrm{H})$ which means "the Prophet Muhammad came to Medina when people made bai' as salam on dates for one or two years. So he said, whoever makes a salam transaction on dates, then do it with a certain scale and dose." ${ }^{28}$ This process of selection or transition from naṣ general to naṣ specifically is called istiḥsān bin al-nas.. ${ }^{29}$

2. Istihsān bi al-maslahah is a transition from kult (global) provisions to khaș (special) provisions or transitions from qiyās al-jât provisions to qiyās alkhafi because there is a benefit that desires so. For example, look at the patient's genitals by a doctor. Seeing other people's genitals is basically forbidden, but because there is a benefit, a doctor is allowed to see the aurat of the patient he is handling.

3. Istịhsān bin al- 'urf is a transition from kult (global) provisions or qiyās al-jať to provisions that have become common practice. For example, istisna transactions, where basically it is never mentioned in nas even it is contrary to nas because there are hadiths that say: "may not sell something that does not exist". But because in reality this transaction is commonly practiced by the community, this transaction is also permissible, even though it is contrary to general provisions.

\footnotetext{
27 Abdul Wahab al-Khallaf, Mașadir al-Tashrī’ fì Mā Lā Naṣ Fīh (Kuwait: Dar al-Qalam, 1983), 71.

${ }^{28}$ Muhammad Ibn Ismail Ibn al-Mughirah al-Bukhāri, Șahih al-Bukhāri (Beirut: Dar al-Fikr, 1981), 44.

${ }^{29}$ Abdul Wahab al-Khallaf, Maṣadir al-Tashrī’ fì Mā Là Naṣ Fīh, 82.
} 
Fourth, al-mașlahah. Imam al-Ghazali said that in principle al-mașlahah is taking something that is useful and rejecting something that is harmful. ${ }^{30}$

As explained earlier that the division of al-mașlahah in terms of quality and importance is divided into three, namely; al maṣlahahal-dañ riyyah, al-maṣlahah alhajjiyyah, and al-maslahahal tahsiniyyah. Whereas, if viewed from the aspect of the content it is divided into two namely al-maslahah al-ammah and al-mașlahah alkhāsșah. And if you want to see in terms of change or not, it is divided into two, namely al-mașlahah al-tsābitah and al-mașlahah al mutaghayyirah. Then finally when viewed from its existence, it is divided into three namely al-mas lahah al-mu'tabarah, al-maș lah ah al mulghah, and al-maș lahah al-mursalah. ${ }^{31}$

Fifth, al-istiṣhāā; The al-istiṣhāb method, according to Ibn al-Qayyim alJauziyyah al-istiṣhāb, is استدامة اثبات ما كان ثابنا أو نفي ما كان منفيا which the meaning of enacting a predetermined law or denying a law that did not exist before. He also divided it into three important parts, namely; First, it is al-istiṣhāa al-barā'ah alaṣliyyah which is an al-istiṣha a $b$ which enforces a law according to its original law or sometimes referred to as istishāb al-barā'ah al-'adam al-aṣliyyah which is an al-istiṣhāa b who considers that something is deemed to have no law as long as there is no argument that shows that something has been determined by the law for him, and this condition continues to apply. ${ }^{32}$

For example, the ability to use trees and fruits in the forest, as long as there is no evidence or argument that shows that the forest has been owned by someone. Second, al istiṣhāa al-waṣ fi al-muśbit li al-hukmi al-Shar'i hattā yuśbita khilāfahu. It is an al istiṣha $\bar{a} b$ which implies that a character that has been established against a shar'i law is deemed to be valid as long as there is no argument that cancels it. For example, in the matter of marriage as long as there is no argument that shows that there is a divorce between husband and wife, then they continue to be counted as husband and wife. $^{33}$

Sixth, al-'urf, Next, after the al-istiṣhāb method is the al- 'urf method. Al- 'Urf means a habit, whether in the form of language or action, which clearly applies in the

\footnotetext{
${ }^{30}$ Nasrun Hoerun, Ușūl al-Fiqh (Jakarta: Logos Wacana Ilmu, 1999), 114.

${ }^{31}$ Abu Hamid M. al-Ghazali, al-Muștafā min 'ilm al-Ușūl, 113.

${ }^{32}$ Ibnu al-Qoyyim al-Jauziyyah, I'làm al-Muwaqqi' īn 'An Rabb al- 'Alamīn (Beirut: Dar al-Jil, 1973), 44.

${ }^{33}$ Abu Muhammad Zahrah, al-Jarīmah wa al- 'Uqūbah fi Fiqh al-Islāmī, 207.
} 
life of society and society is not foreign to him. There are also two habits, namely: Habits that are general in nature that apply to all members of the community and special habits that only apply to some communities, or to certain groups. ${ }^{34}$

Making al-'urf as a part of Islamic law is actually nothing but a manifestation of the benefit and appreciation of Islam for the culture and communal or individual creative potential. It also means Islamic hospitality towards a local culture that is very likely to be able to interact peacefully and strengthen each other with universal Islamic values. Because among those benefits is to preserve or preserve what is used to apply in a society, or with other meanings that have become customary for them from generation to generation. So as long as the customs and habits do not conflict with Islamic law, ${ }^{35}$ Because, if this custom or custom is abolished, then usually it will cause difficulties. $^{36}$

Thus, the logics of ijtihäd is dominantly based on human reasoning, extracting from revelation within a certain context. The theories used are merely humanreasoning and creation. They are subject to be more elaborated, and modified based on current situation.

\section{Islamic Legal Teleology; al-Maqashid al-Syar'iyyah}

Abdul Rahman Zaid al-Kailani argues that the purpose of Islamic law is to realize human welfare as a whole in the life of the world and the afterlife. So to achieve these goals is needed to at least 3 special media. First, 'amaliyyah ibādah ritual. Second, iqāmah al-'adl (upholding justice), and third, idkhāl al'urf(enter 'urf) in the value of mashlahat. These three theories obtain this goal known as maquassid alshan' 'ah. ${ }^{37}$

Maqūşid al-shañ 'ah ${ }^{38}$ was born together with the coming of Islam and will continue into the future. ${ }^{39}$ Al-maqāşid al shañ 'ah is a methodological study that has a

\footnotetext{
${ }^{34}$ Abdul Wahab al-Khallaf, Mașadir al-Tashrī’ fì Mā Lā Naș Fīh, 99.

${ }^{35}$ Muhammad Khalid Mas’ud, Hukum Islam dan Perubahan Sosial (Surabaya: Al-Ikhlas, 1995), 23.

${ }^{36}$ Yusuf Musa, Tārīkh al-Fiqh al-Islāmī (Kairo: Dar al-Kitab al-'Arabi, 1958), 14.

37 Abdul Rahman Zaid al-Kailani, Qawa'id al-Maqasid 'inda al-Imam al-Shathibi 'Irdan wa Dirasatan Tahlilian (Suriah: Dar al-Fikr al-'Arabi, 2000), 44.

${ }^{38}$ Maqāşid al-sharī'ah consists of 2 sentences namely maqāşid as the 'jama form of maqşūd which is derived from the qāşada syllable which means purpose, desire and intentionality. Whereas al Sharī'ahia comes from the word syara'a in language means the road to the source of water or the road to the source of life. So if the meaning of maqāşid al-sharī'ah is presented is the goals of the source of life both in the
} 
central position in the Muslim ijtihād at all times and opportunities. Maqāşsid alshañah is considered to be a very central because it is a study of ijtihādiyyah capable of showing a law that has no texts in the Qur'an or in al-Hadith. So every mujtahid is obliged to know the theory and purpose of maqusşid al-shan' 'ah even including the reason why the verse was revealed in a condition and problem in Islamic society. If observed properly, the determination by the Prophet Muhammad against a law is always based on $a s b \bar{a} b$ the law was revealed. So this is the central key to the study of maqāşid al-sharīah in Islam. ${ }^{40}$

Shatibi explained that some of the points which are important elements of the maqūşid al-shañah are for the following primary needs in sequence, namely: a). Keeping religion (hifdz al-din), b). Maintain the soul (hifdz al-nafs), c). Maintain reason (hifdz al-'aqI), d). Maintain offspring (hifdz al-nasl), e). Keeping property (hifdz al-māl). By keeping the five components above according to him is to ensure safeguards against masculinity and rejection of harm. ${ }^{41}$ Thus the concept of maqāşid al-shan'ah, in any case is always aimed at one thing, namely to the maslahah or goodness in general. The concept developed by al-Shatibi is very focused on the substance of a text which is then connected with a case and reality. ${ }^{42}$ Al Qaradawi interpreted it as a goal that was targeted by texts and particular laws to be realized in human life.

Thus, the urgency of maqūşid al-shañ 'ah as Islamic Law can be summed up in the following considerations: ${ }^{43}$

world and in the hereafter. See Hans Wehr, A Dictionary of Modern Written Arabic (London: McDonald and Evan Ltd., 1980), 765-767.

39 Abdul Manaf, Putusan Badan Peradilan di Indonesia dalam Sengketa Perlindungan Anak (Jakarta: UIN Jakarta Press, 2017), 31.

${ }^{40}$ Didi Suardi, Tinjauan maqāşid al-sharī’ah Terhadap Mekanisme Pembiayaan Murabahah Pada Bank Syariah (Banten: Cinta Buku Media, 2016), 50.

${ }^{41}$ Muhammad Hanif Hakim, Konsep maqāşid al-sharī'ah al-Shatibi, Studi Aplikatif Terhadap Hukum Kartu Kredit”, UIN Sunan Kalijaga Yogyakarta, 2009. http://digilib.uin-suka.ac.id/1913/(Diakses 27 September 2017).

42 Al-Shathibi, Muwāfaqāt (Beirut: Dar Ibnu 'Affan, 1997), 256. See also Wahbah Zuhaily, Ushūl al-Fiqh al-Islāmiy (Beirut: Dar al-Fikr, 1986), 77, and Didi Suardi, Tinjauan maqāşsid al-sharì'ah Terhadap Mekanisme Pembiayaan Murabahah Pada Bank Syariah, 55., and Muhammad Ridwan Abdul Aziz dan Muhammad Shahih Mohammad Nuh, The Role of the Five Major Shari'ah Legal Maxims in The Establishment of maqāşid al-sharī'ah in Islamic Financial Products: A Discussion on Some Cases, European Journal of Business and Management, 63-65.

${ }^{43}$ Didi Suardi, Tinjauan maqāşid al-sharī'ah Terhadap Mekanisme Pembiayaan Murabahah Pada Bank Syariah, 56. See also Abdul Manaf, Putusan Badan Peradilan Agama di Indonesia dalam Sengketa 
1. Maqāşid al-shañ 'ah is part of Islamic law originating from Allah's revelation to the Prophet Muhammad which is applied in the social life of the people even in national and international life.

2. The implementation of the maqūssid al-shañ 'ah was a success and good effort of the reformers of Islam. That is because, above all else, the process of mu'amalah can run well and be fair.

3. The form of maqāşid al-shañ 'ah has become a measure and is right in deciding a case for the purpose of goodness ( 'urf) and for rejecting damage that will have an impact on society and the social system at large.

\section{E. Socio-cultural Laws and Values: Theoretical Perspective I}

Mochtar Kusumaatmadja argues that in the Indonesian context, some of the main obstacles that sometimes cause anxiety and shock in society, appear if what is to be changed is identical to the national personality. This happens in addition to the nature of the heterogeneity of the Indonesian people, also because of differences in the level of progress, religion, language and even the education of the people. So this is a number of obstacles that are often faced today. ${ }^{44}$

As for Roscoe Pound, it was emphasized that the social realities like it or not will have an impact on renewing a law in society. In fact, he called it a law of renewal that was adjusted to the situation and conditions. The concept of "law as a tool of social engineering" which is the core thought of the flow of Pragmatic Legal Realism. It clearly implies this. ${ }^{45}$ Then, further, according to Mochtar Kusumaatmadja, the concept of law has become a means of renewing Indonesian society, which is currently wider in scope than in the United States where it was born. The reason is that it shows more legislation in the process of legal reform in Indonesia, which then adjusts to the needs of the community. ${ }^{46}$

The nature of the new mechanism is seen by the use of the term "tool" by Roscoe Pound. That is why Mochtar Kusumaatmadja is more likely to use the term "means" rather than "tool". In addition to being adapted to the situation and conditions

Perlindungan Anak, 30., and John L. Esposito, Women in Muslim Family Law (Londan: Syracuse University Press, 1982), 101., and Al-Syathibi, Muwāfaqāt (Beirut: Dar Ibnu 'Affan, 1997), 9.

${ }^{44}$ Mochtar Sumatjaya, Hukum Masyarakat dan Pembangunan Hukum Nasional (Jakarta: Rajawali Group, 1976), 70.

${ }^{45}$ Roscoe Pound, Filsafat Hukum (Jakarta: Niaga Media Press, 1996), 109.

${ }^{46}$ Mochtar Kusumaatmadja, Hukum Masyarakat dan Pembangunan Hukum Nasional, 83. 
in Indonesia, the conception was also related to the cultural philosophy of Northrop and policy-oriented from Laswell and McDougal. Then everything that appears from a good goal becomes a means for law enforcement that has been agreed upon by the community as a shared values.

For example, legal jurisprudence in Indonesia has an important role, but not much. Another case in countries that adopt a precedent system. Of course, the role of jurisprudence will be far more important. So, the implementation of legislation that aims to reform it can run as it should, the legislation that was formed should be in accordance with what is at the core of the thinking of the sociology of jurisprudence, that good law should be in accordance with the law that lives in society. So, it reflects the values that live in society. ${ }^{47}$

Studies of law or jurisprudence also pay attention to the influence of values on the legal system which gives rise to the concept of "law of culture". Lawrence Friedman (2006) said that the legal culture can be formulated as "attitudes and values related to behavior, the law and its institutions, both positively and negatively." It aims to show that the legal system applies in society can be different from the legal system that applies in other communities. The difference is because the reality that exists in a society is far different from other realities: language, habits, or differences in race and ethnicity. ${ }^{48}$

In addition to this, the differences in the legal system between one community and another are based on differences in the needs of the community. These life needs to bring out the values and attitudes of the community. Where it is realized by a series of rules and norms in a legal system. Furthermore, the legal system functioned to preserve the existing value system in the community. ${ }^{49}$

Kluckohn Pelly (1994) also argues that cultural values are a broad-scope concept that lives in the minds of most citizens of a society, about what is most valuable in life. The series of concepts are mutually related and constitute a system of cultural values. Functionally, this value system encourages individuals to behave as determined. They believe that only by acting like that will they succeed. The value

\footnotetext{
${ }^{47}$ John Austin, The Province of Jurispridence (Jakarta: PT. Gramedia, 2004), 61.

${ }^{48}$ Lawrence Friedman, Sistem Hukum (Bandung: PT. Nusa Media Group, 2009), 104-107.

${ }^{49}$ Mochtar Kusumaatmadja, Hukum Masyarakat dan Pembangunan Hukum Nasional, 88.
} 
system becomes a guideline that attaches emotionally to a person or a group of people. Therefore, changing the human value system is not easy. Because, these values are the ideal form of the social environment or the conceptual form of their culture, which seems to be outside and above the individual citizens of the community. ${ }^{50}$

Then there appear to be five main problems of human life in every culture that can be found universally, namely:

1. The nature of life.

2. The nature of work or to work.

3. The nature of space and time.

4. The nature of human relations with the environment.

5. The nature of human and human relations

Various cultures conceptualize this universal problem with various variations. Like the first problem, which is about the nature of human life. In many cultures influenced by Buddhism, for example, life is bad and sad. Therefore, the pattern of life of the people seeks to extinguish that life in order to obtain nirvana and to exclude any actions that can add to the series of life again (re-incarnation).

The second problem, concerning the nature of work or work in life. There are cultures that see work as an attempt to survive. This group is less interested in hard work. But there are also those who consider work to get status, position, and honor. But there are those who argue that work to enhance achievement. They are oriented to achievement, not to status. The third problem, concerning human orientation towards time. There are cultures that see the importance in the past, but some see the present as the focus of effort in their struggle. On the contrary, there are those who look far ahead. Different views in this time dimension greatly influence the life planning of the community. ${ }^{51}$

\section{F. Law as a System and Community Structure: Theoretical Perspective II}

As explained earlier, that law as a national subsystem, implies that law is not only a single system in society, independent, autonomous but rather part of other social subsystems such as economics, politics, social, culture and legal consequences as

\footnotetext{
${ }^{50}$ R.J. Kilcullen, Rawls, A Theory of Justice (USA: Hardvard University Press Camridge, 1971), 30.

${ }^{51}$ Muhammad Syukri dan Tim, Hukum dalam Pendekatan Filsafat, 330-331.
} 
part of other social subsystems. Of course, it feels odd, not complete without understanding other social systems. If the economic system does not work, it is impossible for the law to be upright. On the contrary, the people will not be comfortable, safe, if the law is not upright. ${ }^{52}$

It is known that law as a value system as well as a subsystem of the social system actually describes that law is a foundation of life that is not easily reconciled, and often in contrast to the legal behavior of the community that should be. The difficulty of harmonizing the law is inseparable from non-juridical factors that live and develop, one of which is legal culture. Culture as a product of society is very diverse and different, not only the people with one another are different so that due to social levels in the environment, for example, the legal culture of a trader with a teacher, a driver with employees, and so on. ${ }^{53}$

Lawrence Friedman describes the components of the legal system including structure, substance and legal culture. So all three must go hand in hand, namely, the structure must be strong, credible, accountable, and capable. The substance must be in harmony with the sense of justice of the community, while the legal culture must support the upholding of the law. If one of them is lame, for example, the structure of the apparatus is not accountable, credible and accountable, it is impossible for the law to be enforced properly. ${ }^{54} \mathrm{He}$ mentioned that this was named after the symbiotic nat ure of mutualism, namely supporting the growth and upholding of the law and vice versa being parasitic, which inhibits the growth and development of the law.

Emile Durkheim outlines the functional relationship between law and society by first classifying society into two, namely: organic solidarity and society based on mechanical solidarity. Applied concept of human in society are divided into 2 types, namely first, characterized by rules in society that are not so detailed and official, do not recognize the differentiation and specialization of law enforcement agencies because their legal habitat is small communities with high levels of homogeneity, both objective aspects, the interests, as well as the people, so that the simple rules are felt to

\footnotetext{
${ }^{52}$ Compare, Ali Ahmad al-Jurjani, Hikmah al-Tashri 'wa Falsafatuh (Beirut; Dar al-Fikr al-Maraghi, 1996), 55.

${ }^{53}$ Abdul Ghafur Anshari, Filsafat Hukum Sejarah, Aliran da Pemaknaan (Yogyakarta: Gadjah Mada University Press, 2006), 95.

${ }^{54}$ Lawrence Friedman, Sistem Hukum (Bandung: PT. Nusa Media Group, 2009), 104-107.
} 
guarantee the sustainability of the social system. Second, the second type of society, namely the very high level of specialization, whose rules of recognition is based on a professional judgement.

\section{G. Effect of Legal Culture on the Function of Law: Theoretical Perspective III}

Today's human life is indicate that law as a norm of behavior is very important so that people's behavior does not deviate. The role of law is very dependent on the situation. In developing countries the law takes on the role of social control as well as a driver of behavior towards national goals, namely increasing welfare and social justice. In order for people's behavior not to be in conflict with the law, of course, total public awareness is needed to comply and obey the law. That awareness is a bridge between law and community behavior.

Legal awareness according to Friedman is closely related to the legal culture of society. In other words, it can be explained that the level of legal awareness of high or low society can be seen in its legal culture if the legal culture tends to be positive, proactive towards legal ideals, of course, the people have high legal awareness. In this case, the legal function undergoes expansion. What began as social control and retention of social patterns shifted the direction towards changes in behavior desired by law. ${ }^{55}$

\section{H. Sociological Dimensions of Islamic Law}

Ahmad Mushtafa said there is a very close connection between the law on the one hand and the socio-cultural values in the other hand. This has been proven by several legal anthropologists, both pioneering and theoretical. According to him, the relation between the law and the socio-cultural values of the people turns out that the law can reflect the good values of life and the example in the community itself. ${ }^{56}$ Matured communities can always learn in social processes. This process leads to the choice of the community autonomously. There is always a process and value transition

\footnotetext{
55 Abdul Ghafur Anshari, Filsafat Hukum Sejarah, Aliran da Pemaknaan, 66.

${ }^{56}$ Cultural values are values that live in the minds of members or citizens who aim as the highest guideline for acting, thinking, mentality, and even everyday behavior. See. Muhammad Syukri dan Tim, Hukum dalam Pendekatan Filsafat (Jakarta: PT. Kharisma Putra utama, 2015), 325.
} 
in making autonomous choices: which values should be abandoned and which ones should be maintained properly. ${ }^{57}$

The complexity of the study of Islamic law shows that the problem of social change is an important issue and needs to get its own attention, especially when establishing a law. ${ }^{58}$ This is the reason why in the study of Islamic law, there are many legal rules that are directly related to social change. For example, Zainal Abidin bin Ibrahim summarizes some important rules regarding this matter as follows: ${ }^{59}$

العادة محكمة

"Customary habits that apply in a society can be a law"

$$
\text { المعروف عرفا كالمشروط شرطا }
$$

"Something that has been considered good and applies in the middle of people's lives is the same as the conditions that apply in a transaction"

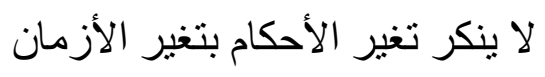

"Not denial the existence of legal changes due to changing times"

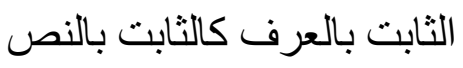

"Something specified with " urf is equal to something specified with naș"60

Zainal Abidin bin Ibrahim stressed that with the existence of such rules would certainly raise questions, what laws could change with changing times and circumstances? So, to answer this question, it needs to be understood that the discussion of Islamic law theorists ( uṣu liyȳ̄n) divides Islamic law into two important things, namely; First, the law can be captured by 'illat or rational (ma'qūlil ma'nā). Second, laws that cannot be captured 'illat or irrational (ghairu ma'qūlil ma'nā). (the definition contained in the nas cannot be rationalized). ${ }^{61}$

Ibn al-Qoyyim al-Jauziyyah $(1350 \mathrm{~m})$ said that there are at least two important legal issues that can accept changes or which can be entered by mujtahid, namely; 1). Issues that have no law in nas directly, and. 2). The problem found is the law in nas but naș is dzannī and not qaț'i . Because, when there is a dzannī law, then over time, the law

\footnotetext{
${ }^{57}$ Ahmad Mushtafa,Filsafat Hukum, Membangun Hukum, Membela Keadilan (Yogyakarta: Kanisius Group, 2009), 44.

${ }^{58}$ Soejono Soekanto, Pokok-pokok Sosiologi Hukum (Jakarta: Rajawali Press, 1988), $5^{\text {th }}$ publishing, 89.

${ }^{59}$ Zainal 'Abidin Ibn Ibrahim Ibn Nujaim, al-Aṣbah wa al-Nazāir (Kairo: Al-Bab al-Halabi, 1968), 94.

${ }^{60}$ Ahmad al-Hajji al-Kurdi, al-Madkhal al-Fiqh: al-Qawā'id al-Kulliyyah (Damaskus: Dar al-Ma'arif alTiba'ah, 1979), 60.

${ }^{61}$ Zainal 'Abidin Ibn Ibrahim Ibn Nujaim, al-Aṣbah wa al-Nazāir,98.
} 
is felt to be no longer relevant to the life of a society. Thus, the mujtahid in the community may provide a new fatwa which is more appropriate to the conditions and conditions of the community. ${ }^{62}$

Furthermore, please also note that there has been a lot of attention to the problem of this social condition. In fact, it already exists or has been practiced since the Prophet Muhammad. In a history it is said that, had come to the Prophet Muhammad a man, then the man asked; "O Messenger of Allah, is it acceptable to repent someone who has killed someone else?" Rasulullah SAW saw the man in a state of despair and regret for his actions, and at the same time repented to Allah. Therefore, the Prophet Muhammad replied: "Yes, repentance is accepted". On another occasion, the noble Apostle also came to another man with a red face and drawn a sword in his hand. He asked the Messenger of Allāh with the same question, and the Messenger of Allāh answered him with "no repentance". ${ }^{63}$

In these two different stories, the Prophet Muhammad gave a different response between the first and the second. Where the first Prophet Muhammad replied that his repentance was received by Allah, because he came with great sincerity and great remorse to Allah, so he was almost desperate. Whereas, the second questioner, the Prophet Muhammad responded that his repentance was not accepted because his sincerity and regret were not the same as the condition of the first questioner.

By observing these two different cases a legal provision may differ depending on the conditions and characteristics of each case that is being faced, as the Prophet Muhammad gave an example above. This is a necessity that must be known by the mujtahid in deciding a law based on the principle of justice in the midst of society.

\section{From the sociological aspect towards the transformation of legal values}

\footnotetext{
${ }^{62}$ Ibnu al-Qoyyim al-Jauziyyah, I'läm al-Muwaqqi'īn 'An Rabb al- 'Alamīn,132. See also Ibnu al-Qoyyim al-Jauziyyah, I'lām al-Muwaqqi'īn 'An Rabb al-'Alamīn,89. And see also Jarīmah ta'zīr is a sentence that is not determined by naș, but is given the authority of punishment and the matter is left to the court or the authorities, in order to achieve benefit in society. See. Lih. Zuraida, Ta'zīr dalam Penegakan Qanun No. 14 Tahun 2003 tentang Khalwat (Banten: Cinta Buku Media, 2017), 62-63.

${ }^{63}$ Fathi al-Duraini, al-Fiqh al-Islāmi al-Muqāran ma'a al-Madzāhib (Damaskus: Mathba'ah Tarabin, 1979), 62. See also Muhammad Baltaji, al-Manāhij al-Tashrī' fi al-Qarn al-Thān̄̄ al-Hijrī (Riyadh: Universitas Islam al-Imam Muhammad Ibn Su'ud Press, 1987), 865. And see also Aprianif, Pandangan Hukum Islam terhadap Dewasa Dini, Analisis Konsep Taklif Berdasarkan Pubertas Prekoks dan Gifted, 88.
} 
The Prophet Muhammad himself when giving opinions on a matter related to the law, was not fixed on just one pattern. However, it is very considerate of the skills and situation of the person who will carry out the law. In fact, there were Bedouins who entered Islam, then the concerned asked to be taught by the Prophet about Islam. The Prophet did not teach and directly obliged him to carry out the Pillars of Islam, but only asked the person concerned to commit not to lie. Avoid lying. So, Islam is taught as a very social and contextual religion. ${ }^{64}$

The sociological aspects of the development of Islamic law also refer to the tradition of thinking of al-Imām al-Syāfii. Imām Syāfii has an old legal opinion, known as qaul qadìm. Qaul Qadìm Imām Syäfii refers to many of his opinions which are influenced by the atmosphere and development of the people in Iraq. On the other hand, Imām Syāfii also has a new opinion (qaul jadidd). This new opinion is colored by the development of Egyptian society. The change in legal thoughts and opinions is inseparable from sociological factors.

So, it can be explained that the sociological aspects of Islamic law are then the media of Islamic law as a tool of social transformation. In the case of zakāh and zakāh fitrah, Muslims are not taught to tithe exactly like the Prophet with wheat for example. But, in the context of Indonesian society, it is permissible to make alms with rice. Rice is the staple food that applies in Indonesia. There is no such thing during the Prophet.

From the last description, it is very possible to carry out a transformative process for waqf. Endowments do not have to be with immovable property. However, it is permissible with cash waqf, tree waqf, waqf al-Qurān, skill endowments and patent rights as well as plant waqf or professional honorarium for a job. So, in such a way, if we pay attention to the sociological aspects of Islamic law, we find a series of transformative instruments for their legal values.

\footnotetext{
${ }^{64}$ Ahmad Fauzi, 'Abd al Hamid, "Implementing Islamic Law with in a Modern Constituional from Work", Chalengges and problems in Contemporary Malaysia, in Islamic Studies. Vol. 48. No.2 (2009), 157-187., and see also Roger, Cotteril "Common Law Approaches to the Relationship between Law and Morality", dalam Ethical Theory and moral practice, Vol. 3. No.1 (2010), 54-65., and Early, Joseph E Lowry"'Islamic Legal Theory:The Risala of Muhammad Ibn Idris al-Shafi'I, in Studies Islamic Law and Society,", Review by Kecia. 'Ali, in Review of Middle East Studies. Vol.44. no.2 (2010), 247-249. And Mohammad Hasyim Kamali, "Maqashid al-Shari'ah, The Objectivies of Islamic Law", in Islamic Studies, Vol.38.No.2(2009), 155-161., and John Makdisi, "Legal Logic and Equity Islamic Law", in The American Journal of Comparative Law, Vol.33.No.1 (2010), 63-92.
} 


\section{J. Conclusion}

It is certain that law has the potential for change in a society if there are different conditions and characteristics, even in the same case and type. This is a challenge for every mujtahid to improve their scientific quality and understanding of the history of Islam, especially the time of companions (sahäbah) and tabi'in and moreover the nas al-Qur; an and hadith as guidelines for Islamic life in carrying out the Shariah. At the same time, as a link in the systematization ladder and the formation of values and knowledge of Islamic law. ${ }^{65}$

In addition, an understanding of social theories, especially related to the relationship between law and social change, becomes a necessity. Because, as explained above (theoretical exposure), the law is not in empty space and is empty of culture and tradition. However, the law will always live and die in an environment of culture and tradition. Values, culture, the structure of society and the scope of legal social work will always interact each other.

In line to the rapid social change caused by technical innovation, theories of legal logics and reasoning in Islamic law should be improved as the early generations have done: conserving the essence of moral ethics of law and modifying the legal logic based on socio-legal transformation (respecting local wisdom, referring to public interest, combining practicality and instrumentalizing law as a tool for social engineering) as it is described above is one of examples. Further elaboration and innovation is still on demand.

\footnotetext{
${ }^{65}$ Compare Noel J. Coulson, A History of Islamic Law (Edinburgh University Press, 1994), 3.
} 
Logics, Objectives And Sociological Sides of Islamic Law:

Re-Structuring Fiqh For Social Change

\section{Bibliography}

'Abd al Hamid, Ahmad Fauzi, "Implementing Islamic Law with in a Modern Constituional from Work", Chalengges and problems in Contemporary Malaysia, in Islamic Studies. Vol. 48. No.2 (2009),

Al-Qur'ān al-Kan̄m

Aprianif, Pandangan Hukum Islam terhadap Dewasa Dini, Analisis Konsep Taklif Berdasarkan Pubertas Prekoks dan Gifted, Banten: Cinta Buku Media, 2017.

Al-Amidi,Shaifuddin.al-Ihkām fi Ușūl al-Ahkām, Beirut: Dar al-Fikr, 1981.

Al-Baqi,Muhammad Fuad Abd.al-Mu'jam al-Mufahras li al-Alfādz al-Qur'ān al-Kar̄m, Beirut: Dar al-Fikr, 1989.

Al-Duraini,Fathi.al-Fiqh al-Islāmi al-Muqāran ma’a al-Madzāhib, Damaskus: Mathba'ah Tarabin, 1979.

Al-Ghazali,Abu Hamid Muhammad.al-Muștafâ min 'ilm al-Ușūl, Beirut: Muassasat alRisalah, 1997.

Al-Jauziyyah,Ibnu Al-Qoyyim.I'lām al-Muwaqqi în 'An Rabb al-'Alamīn, Beirut: Dar al-Jil, 1973.

Al-Khatib,Muhammad Ajaj.Ușūl al-Hadith: 'Uhūmuhu wa Muṣtalāhuhu, Beirut: Dar al-Fikr, 1981.

Al-Khalil, 'Ata.Kajian Ushul Fiqh Mudah dan Praktis, Bogor: Pustaka Toriq al-Izzah, 2008.

Al-Kurdi,Ahmad al-Hajji.al-Madkhal al-Fiqh: al-Qawā'id al-Kulliyyah, Damaskus: Dar alMa'arif al-Tiba'ah, 1979.

Al-Munawwar,Said Agil.Hukum Islam dan Pluralitas Sosial, Jakarta: Penamadai, 2004.

Al-Namr,Abdul Mun'im.al-Ijtihād, Kairo: al-Haiah al-Misriyyah al-'Ammah, 1987.

Al-Qaradawi, Yusuf.Madkhal li Dirāsāt al-Shañ̄’ah al-Islāmiyah, Kairo: Maktabat al-Wahbah, 1990.

Al-Shatibi.al-Muwāfaqāt fì uṣūl al-Ahkām, Kairo: al-Maktabah al-'Ilmiyyah, t.t.'Aliyah,Samir. 'Ilm al-Qāmūn wa al-Fiqh al-Islāmī, Beirut: Muassasah al-Jami'ah, 1996.

Al-Shidqdy,Muhammad Hasbih.Falsafah Hukum Islam, Jakarta: Bulan Bintang, 1988.

Al-Shidqi,Tengku Muhammad Hasbi.Sejarah dan Pengantar Ilmu al-Qur'an dan Tafsir, Semarang: Pustaka Rizki Putra, 2000.

Al-Syaukani,Muhammad Ibn Ali Ibn Muhammad.Nail al-Auțār, Beirut: Dar al-Fikr, 1978.

Al-Syarastani, Muhammad Abdul Karim.al-Miāl wa al-Nihāl, Kairo: Mustafa al-Bab alHalabi, 1967

Baltaji,Muhammad al-Manāhij al-Tashn̄' fi al-Qarn al-Thān̄ al-Hijn̄̄, Riyadh: Universitas Islam al-Imam Muhammad Ibn Su'ud Press, 1987.

Baltaji,Muhammad.Metodologi Ijtihād Umar bin Khattab, diterj. Masturi Ilham, Jakarta: Khalifa, 2005.

Bukhari,Imam.Șah̄̄h al-Bukhān̄, Beirut: Dar al-Fikr, 1981.

Cotteril Roger , "Common Law Approaches to the Relationship between Law and Morality", in Ethical Theory and moral practice, Vol. 3. No.1 (2010)

Coulson,Noel J. A History of Islamic Law, Edinburgh University Press, 1994.

Dutton, Yasin. Asal Mula Hukum Islam, Yogyakarta: Islamika, 2003. 
Early, Joseph E Lowry'Islamic Legal Theory:The Risala of Muhammad Ibn Idris al-Shafi' I, in Studies Islamic Law and Society,", Review by Kecia. 'Ali, in Review of Middle East Studies. Vol.44. no.2 (2010)

Hoerun,Nasrun. Ușūl al-Fiqh, Jakarta: Logos Wacana Ilmu, 1999.

Ham, Musahadi.Evolusi konsep Sunnah dan Implikasinya terhadap Perkembangan Hukum Islam, Semarang: Aneka Ilmu, 2000.

Hasaballah,Ali.Ușūl al-Tashr̄̄’ al-Islāmī, Kairo: Dar al-Ma'rifah, 1976.

Jamil,Fathurrrahman.Filsafat Hukum Islam, Jakarta: Logos, 1999.

Jaya,Burhanuddin. Gerakan Pembaharuan Pemikiran Islam, Yogyakarta: Tiara Wacana, 1995.

Kamali, Mohammad Hasyim, "Maqashid al-Shari'ah, The Objectivies of Islamic Law", in Islamic Studies, Vol.38.No.2(2009)

Makdisi, John, "Legal Logic and Equity Islamic Law", in The American Journal of Comparative Law, Vol.33.No.1 (2010)

Manan,Abdul.Reformasi Hukum Islam di Indonesia,Jakarta: Raja Grafindo Persada, 2006.

Mandzur,Jamaluddin Muhammad bin Makarram.Lisān al- 'Arab, Beirut: Dar al-Fikr, 1990.

Mas'ud,Muhammad Khalid.Hukum Islam dan Perubahan Sosial, Surabaya: Al-Ikhlas, 1995.

Musa,Yusuf. Tān̄̄kh al-Fiqh al-Islāmī, Kairo: Dar al-Kitab al-'Arabi, 1958.

Nujaim,Zainal 'Abidin Ibn Ibrahim. al-Aṣbah wa al-Nazāir, Kairo: Al-Bab al-Halabi, 1968.

Khallafi,Abdul Wahab.Ilmu Ușūl al-Fiqh wa al-Khulāṣah al-Tānnkkh al-Tashn̄’, Mesir: Dar alMadani, 1988.

Praja,Juhaya S. Epistemologi Hukum Islam, Jakarta: IAIN Jakarta Press, 1988.

Poerwadarminta, Kamus Umum Bahasa Indonesia, Jakarta: Balai Pustaka, 1976.

Soekanto,Soejono.Pokok-pokok Sosiologi Hukum, Jakarta: Rajawali Press, 1988.

Zaidan,Abdul Karim.al-Madkhal li al-Dirāsāt al-Islāmiyyah, Kairo: Dar Umar bin Khattab, t.t.

Zuhdi,Masyfuk.Pengantar Hukum Syari'ah, Jakarta: Haji Mas Agung, 1987.

Zuhaili,Wahbah.Fiqh Imam Syafi' 'i, terj. Jakarta: al-Mahira, 2010.

Zahrah,Abu Muhammad.al-Jañmah wa al-'Uqūbah fi Fiqh al-Islāmī, Kairo: Dar al-Fikr al'Arabi, 1958.

Zuraida, Ta'zīr dalam Penegakan Qanun No. 14 Tahun 2003 tentang Khalwat, Banten: Cinta Buku Media, 2017. 